\title{
"Ut omni tempore inservire queant...". A Reflection on the Structure of Jacobus Handl's Opus musicum and its Association with a Liturgical Context
}

Marc Desmet / marc.desmet@univ-st-etienne.fr

Université de Saint-Etienne, IHRIM (UMR 5317), FR

\begin{abstract}
Due to its ambitious covering of the whole liturgical year and its impressive contents of 374 motets, the Opus musicum by Jacobus Handl Gallus has often been compared to other great liturgical summae of the 16th century such as Heinrich Isaac's Choralis Constantinus. However, few studies, if any, have ever tempted to elucidate the links which could actually associate the musical contents of the Opus musicum and a liturgical context. This task has still to be realised from the start, although many clues seem to converge in favour of a collection of ecclesiastical concerts rather than a series of polyphonic settings of liturgical chant quotations.
\end{abstract}

\section{Key words}

Handl Gallus, Opus musicum, liturgy 


\section{Introduction}

Musicologists who choose to engage in the discussion about liturgy in the Opus musicum by Jacobus Handl Gallus ${ }^{1}$ will likely encounter a large field for new investigation waiting for them. With its 374 motets, the Opus musicum, published in four tomes in Prague between 1586 and $1591^{2}$, can be considered the most ambitious achievement to have been realised by the composer. The music it contains is inspired and has been conceived in subtle relation to the utterance of ceremonial words, making it possible to detect in Gallus a special liturgical sensitivity. This impression is confirmed by the specific context in which this music was conceived and created: more than a simple frame, the ceremonies of the Church have represented both the space and time in which the artistic ornament of Handl's compositions was born ${ }^{3}$, in parallel with the periodical return of seasons and feasts of the liturgical year. In the texts he wrote, the composer showed himself to be sensitive, more than once, to the dimension of decorum and musical ornament in the sanctuary ${ }^{4}$. His music brings light, in a very direct and profound way, to the meaning he was granting to the discursive elements in his compositions, always with respect to the liturgical season. On the other hand, we find the composer often concerned by the ornaments incorporated within the inner space of the sanctuary. His musical creation also seems to reflect this peculiar, spatial dimension, in that it frequently displays structural qualities that can easily evoke sound architectures. This architectural dimension is also perceptible to the listener, and sometimes to a much greater extent than in the contemporary compositions by Lasso or Palestrina.

1 The latest and most accurate monograph devoted to the composer and the sources of his music is MOTNIK, Marko. Jacob Handl-Gallus, Werk-Überlieferung-Rezeption, mit thematischem Katalog. Tutzing: Hans Schneider Verlag, 2012. (Wiener Forum für ältere Musikgeschichte, ed. Birgit Lodes, Bd. 5).

2 RISM [H 1980 to [H 1982 (tomes I to III) and [H 1985 (tome IV). In the catalogue by Marko Motnik, the 374 motets of Opus musicum bear numbers starting from 17 to 390 and are discussed, with concordances to manuscript sources, in p. 471-622. All four tomes of the Opus musicum have been scanned, and are freely accessible via the Digital Collections of the Bayerische Staatsbibliothek in Munich. See, for Tome I:

http://daten.digitale-sammlungen.de/ $\mathrm{db} / 0009 /$ bsb00092000/images/?viewmode=1 (14.11.15).

3 Handl's first place of activity being essentially monastical (in Melk and Zábrdovice) before he came to be employed at the Olomouc bishophric.

4 Especially in the foreword of Tome I, dedicated to the bishops of Olomouc, Prague and Breslau. See HANDL GALLUS, Jacobus. Tomus primus Musici operis... Pragae: Typis Georgii Nigrini, 1586, f. [2]: Sic enim omnes, et singuli in hanc vnam rem incumbitis, ita domus Dei ornamenta omnia colligitis, E् captatis vndiq; vt nihil, quod huc quoquo modo pertinere arbitramini, à vobis negligatur. [Thus each all of you, and each one to this purpose, you apply yourself to gathering every ornament of the house of God, you eagerly look for them in such a way that nothing which would appear to you in any way as being part of it could be found to be neglected]. But also in the Instructio ad musicos (Instruction to musicians) which complements the foreword to Tomus tertius... Pragae 1587, f. [4]-[4v]: Restat, ut vos, qui in aedibus sacris Symphoniae praeestis, obtester, singula ut suis temporibus accommodetis, neve confusioni, quae in domo Dei occurreret, locum ulla ratione faciatis; quod illic forte videtur deesse, alibi resarcietur. [I still have to urgently pray you, who are the directors of the musical forces present in the sacred sanctuaries, to accommodate each piece to the time which it befits, and avoid that there be any cause for whatever confusion in the house of God]. 
It seems no wonder, then, that the Opus musicum should have generated a large amount of secondary literature, including two critical editions ${ }^{5}$, one doctoral dissertation ${ }^{6}$, two independent monographs ${ }^{7}$ and five or six substantial articles ${ }^{8}$. Strangely enough, and in spite of such a wealth of material, it seems that we are still poorly informed about the nature of links that would exist between the Opus musicum and a liturgical context. This is all the more surprising since these links appear to be explicitly suggested by the title pages and divisions of the four volumes, which allude to the liturgical calendar of a full year.

Tome I extends, with 103 motets, from the period beginning at Advent lasting until, and including, Lent. It is divided into three subsections:

1. In Adventu Domini nostri Iesu Christi (26 motets for Advent time)

2. De Nativitate, Circumcisione et Epiphania Domini (28 motets for Nativity, Circumcision and Epiphany)

3. A Dominica Septuagesimae, per Quadragesimam, de Poenitentia (38 motets for Penitential time, from Sunday of Septuagesima through Lent included).

On the title-page of this volume, one can also find an expression commonly found in breviaries, antiphonaries or graduals of the time: Incipit pars hiemalis [Here begins the winter part], as if the collection of motets had an intentional parallel construction with liturgical books from the start.

Tome II contains 70 motets and is devoted to the period beginning with Holy Week and extending until, and including, Pentecost. It is divided into four subsections, the first two of which are related to specific cycles of Holy Week:

4. De Passione Nostri Domini Jesu Christi (3 settings of the Longueval-Passion text ${ }^{9}+13$ motets for Holy Week)

5 1) MANTUANI, Josip - BEZECNY, Emil, eds. Jacobus Handl (Gallus) Opus Musicum, Wien: Artaria, 18991919 (Denkmäler der Tonkunst in Österreich, nos. 12, 24, 30, 40, 48, 51/52), 6 vols. 2) ŠKULJ, Edo, ed. Iacobus Gallus, Opus Musicum, Ljubljana: Slovenska Akademija Znanosti in Umetnosti, 1985-1990 (Monumenta Artis Musicae Sloveniae, nos. 5-17), 13 vols.

6 EGBERT, Louard Edward Jr. The Opus Musicum of Jacobus Gallus: Performance problems of selected motets. PhD. University of Kentucky, Princeton (KY) 1975.

7 1) ŠKERJANC, Lucijan Marija. Kompozicijska tehnika Jakoba Petelina Gallusa [The Compositional technique of Jakob Petelin Gallus]. Ljubljana: Slovenska Akademija Znanosti in Umetnosti, 1963. 2) PONTZ, Stefan. Die Motetten von Iacobus Gallus, Untersuchungen zu den Tonarten der klassischen Vokalpolyphonie. München: Wilhelm Fink, 1996 (Studien zur Musik, hsg Eudolf Bockholdt, n 15).

8 1) ŠKULJ, Edo. Bogoslužno leto v Opus musicum [The liturgical year in the Opus musicum]. Cerkveni Glasbenik [The Church musician], 1991, vol. 84, nos. 4-12, p. 125-145. 2) ACCIAI, Giovanni. Espressione e artificio in alcuni motetti dell' „Opus Musicum“ di Jacobus Gallus Carniolus. In Gallus Carniolus in evropska renesansa II [Gallus Carniolus and the European Renaissance]. Edo Škulj - Danilo Pokorn (eds.). Ljubljana: Slovenska Akademija Znanosti in Umetnosti, 1992, p. 49-78. 3) WILSON, Fredric Woodbridge. Index to the Opus Musicum of Jacob Handl Gallus. In Gallus Carniolus in evropska renesansa II. Edo Škulj - Danilo Pokorn (eds.). Ljubljana: Slovenska Akademija Znanosti in Umetnosti, 1992, p. 207-288. 4) ŠKULJ, Edo. Vprašanje mere v Gallusovih motetih [The question of measure in Gallus' motets]. Cerkveni glasbenik, 1993, vol. 86, nos. 1/3, p. 62-65. 5) WACZKAT, Andreas. Parodie-Motetten in Opus musicum des Jacobus Gallus: Wege zu ihrer Identifizierung und Analyse. Tijdschrift voor muziektheorie, 2003, vol. 8, no. 2, p. 123-133. 6) JEŻ, Tomasz. The Motets of Jacob Handl in inter-confessional Silesian liturgical practice. De musica disserenda, 2007, vol. 3, no. 2, p. 35-46.

9 On the specific history of this text, which combines fragments from the four Gospels, and its original 
5. Lamentationes Ieremiae Prophetae (Complete cycle of the Lamentations of Jeremiah in 9 sections, with adjunction of three motets)

6. De Resurrectione et Ascentione (27 motets for Easter and Ascension time)

7. De Spiritu Sancto (14 motets for Pentecost time).

Contrary to the first tome, the title-page of Tome II does not display any formulas common to liturgical books.

Tome III comprises 57 motets intended for the feasts of Trinity, Corpus Christi and Dedication, as well as for the period lasting between the third Sunday after Pentecost until the start of Advent time. It is divided into three subsections:

8. De Sancta et individua Trinitate (14 motets for the feast of Trinity)

9. De Corpore Christi (12 motets for Corpus Christi)

10. In Dedicatione Templi, et a Dominica tertia post Pentecosten, usque ad Adventum Domini (31 motets for the ceremony of Dedication, and from the third Sunday after Pentecost up to Advent time).

If no mention is made of a formula recalling liturgical books on the title-page of this tome, as was already the case with Tome II, then two peculiarities occurring in the order of its pieces are worth mentioning as unique to this volume. First of all, both sections devoted to Trinity and to Corpus Christi, two feasts which are very close to one another in the liturgical calendar, are not clearly separated in the succession of pieces, but are presented in alternation within a given part setting: motets for eight to six parts, then motets for five parts, then motets for four parts successively display a 'Trinity', then a 'Corpus Christi' subsection. Another peculiarity is found in the presence of motets devoted to the feast of the Dedication, found within the section intended for the long period of tempus per annum (that is, mostly the summer part of the liturgical calendar) situated between Pentecost time and Advent. This inclusion looks like somewhat of an anomaly within the overall distribution of the anthology, since these Dedication pieces would have been more logically expected in Tome IV of the Opus musicum, which parallels a sanctoral cycle. The reason why they are to be found in Tome III instead remains unclear, although the difference of size between these last two tomes of the Opus musicum (Tome III being the shortest, Tome IV the largest) may have played a role in this unexpected disposition ${ }^{10}$.

polyphonic setting in the 16th century, see HEYINK, Rainer. Die Passionsmotette von Antoine de Longueval, Herkunft, Zuschreibung und Überlieferung. Archiv für Musikwissenschaft, 1990, vol. 47, no. 3, p. 217-244. About the more specific link of Handl's Passion settings with this tradition, see FISCHER, Kurt von. Die Passions-Motetten des Jacobus Gallus und ihre Beziehungen zur Passion des Antoine de Longavals. In Gallus Carniolus in evropska renesansa I [Gallus Carniolus and the European Renaissance, I]. Edo Škulj - Danilo Pokorn (eds.). Ljubljana: Slovenska Akademija Znanosti in Umetnosti, 1991, p. 63-70.

10 No less than six Dedication motets (OM III, 27, 28, 35, 36, 37, 43) are to be found in the Opus musicum. Their importance may be linked to the fact that, on the actual premises of Handl's Moravian places of activity (mostly the Praemonstratensian monastery of Zábrdovice and the Olomouc-Kroměříž residences of the Bishop), the rebuilding of churches, as well as the first wave of Counter-Reformation ideals probably gave place to many Dedication ceremonies. See DESMET, Marc. Façade et revers d'une architecture musicale solennelle: la structure de l'Epicedion Harmonicum de Jacobus Handl (Gallus) et ses énigmes non résolues. De musica dis- 
Tome IV is organised according to a different structure, precisely because of its association with the Sanctorale (sanctoral) of the liturgical calendar, which does not refer to seasons but to individual feasts. It is formed of 144 motets divided into six sections-out of which the last one appears only once at the end of the entire collection-meanwhile the succession of the first five is repeated within each of the four divisions of the part settings (motets for $8,6,5$ and 4 parts respectively).

11. In festis beatae Virginis Mariae or De Beata Virgine matre Christi Maria (30 motets for Marian feasts)

12. In communi de Apostolis (32 motets for the common of Apostles)

13. In communi de Martyribus (30 motets for the common of Martyrs)

14. In communi de Confessoribus (29 motets for the common of Confessors)

15. In communi de Virginibus (18 motets for the common of Virgins), the section to which one extra motet is added De Angelis et Archangelis (for Angels and Archangels)

16. Psalmi omnibus sanctis triumphales (3 psalms to all triumphant saints).

It is remarkable that, on the title-page of this last tome, the presence of a subtitle appears, of a type that was already encountered on the title-page of Tome I, but not in Tomes II and III. Following the title, this formula states 'Incipit pars de Sanctis' [Here begins the Sanctoral part], clearly included in order to recall the presentation of liturgical books. Another peculiarity of this tome is the prevalence of part setting upon liturgical divisions, in exactly the same manner as that found in Tome III for the 'Trinity' and 'Corpus Christi' motets. Finally, the very end of the volume, four pieces are included but not entirely related to the main subject. A motet for Angels and Archangels is added at the end of the last 'De Virginibus' section, and three motets for large part settings (one motet for 8 parts, two for 24) masterfully conclude the whole collection.

Title-pages and detailed subsection titles therefore seem to conspire in favour of an apparent and intentional construction of this collection of motets, according to the order of an antiphonarium or a breviarium. That this overall conception should have been associated with the presence of chant quotations within the compositions is yet another question, which remains entirely open to this day.

\section{The evidence of sources}

Printed collections of polyphonic music conceived according to a liturgical order were certainly not a rare thing in the Renaissance and examples are indeed numerous; to be found between the anonymous Lyon Contrapunctus $(1528)^{11}$ and William Byrd's

serenda, 2014, vol. 10, no. 2, p. 101-123.

11 CONTRAPUNCTUS, seu figurata musica super plano cantu missarum totius anni, Lugduni, in edibus Stephani Guaynard, 1528. Sometimes attributed to Francesco de Layolle, this collection, which displays a typographical tour de force showing the presence of chant inside the counterpoint, has been scanned and is accessible free of 
Gradualia (1605-1607). One of the great masterpieces of the early century, Heinrich Isaac's Choralis Constantinus published posthumously in 1550, is a magnificent example in this category ${ }^{12}$. Containing 375 motets conceived for nearly a hundred celebrations all along the liturgical calendar, it has often been taken as a point of comparison by scholars studying the Opus musicum ${ }^{13}$. But other examples could have been no less convincingly chosen for this comparison, and should we look for collections situated closer to Handl, both in time and in space, the Cantiones ecclesiasticae ${ }^{14}$ by Leonhard Päminger (himself a fine connoisseur of the Choralis Constantinus) would then also have been a possible match. This publication of four volumes, printed in Nuremberg between 1573 and 1580, displays a number of characteristics that build an interesting transition between Isaac's and Handl's masterpieces. It shares in common with the latter at least a somewhat similar title-page, and is likewise divided into three volumes following the Temporale (Time Proper), followed by a fourth composed of different pieces. Moreover, this collection appears to have been in Handl's possession; this we can infer from the inventory of the books found at Handl's home after his death ${ }^{15}$. It is therefore not surprising that many scholars, from Friedrich Blume ${ }^{16}$ to Edo Škulj ${ }^{17}$ and Marko Motnik ${ }^{18}$, should have considered this collection from Päminger as a potential model for Handl's. But if we are to believe this assertion, we could then have added in turn at least one more candidate for a model of the Opus musicum, namely, the Silesian composer Johannes Knöfel (1525-1617), whose Cantus Choralis also seems to share many a common feature with Handl's Opus $^{19}$. This collection of polyphonic propers, published in Nuremberg in 1575, is not mentioned in the inventory of Handl's library. However, Knöfel's and Handl's bio-

charge via the Digital Collections portal of the the Bibliothèque nationale de France, Gallica, at page: http:// gallica.bnf.fr/ark:/12148/btv1b8538821j.r=Contrapunctus (06.01.16).

12 ISAAC, Heinrich. Primus [-Tertius] tomus Coralis [!] Constantini. Nornbergae: Hieronymus Formschneider, 1550 [-1555]. This source has been scanned and is freely accessible via the Digital Collections of the Bayerische Staatsbibliothek in Munich. See, for Tome I:

http://stimmbuecher.digitale-sammlungen.de/view?id=bsb00094084 (18.01.16).

13 Authors recalled by Egbert, op. cit., p. 67.

14 PÄMINGER, Leonhard. Primus [-Quartus] tomus ecclesiasticarum cantionum... Noribergae: In Officina Theodorici Gerlazeni, 1573-1580. This document has been scanned and is freely accessible via the Digital Collections portal of the Bayerische Staatsbibliothek in Munich, at page (for Tome I): http://stimmbuecher.digitalesammlungen.de/view?id=bsb00072013 (06.01.16).

15 This manuscript document in Czech, established in 1591, had been published and commented as early as 1888 by Zikmunt Winter in his Malé historie ze života staročeského [Little histories from Old Bohemian life]. Velké Meziřićí: J.F. Šašek, 1888, p. 114 et seq. It was later on included in all Handl studies from Mantuani to Škulj. Edo Škulj published it alongside with a Slovenian translation and a detailed commentary in his Gallusovi predgovori [Gallus' forewords], Ljubljana: Družina, 1991. p. 138-149.

16 BLUME, Friedrich. Protestant Church Music. London: V. Gollancz, 1975 (revised edition from the German original, 2/1965), p. 121.

17 ŠKULJ, Gallusovi, op. cit., p. 143-144.

18 MOTNIK, op. cit., p. 34.

19 KNÖFEL, Johannes. Cantus choralis, musicis numeris quinque vocum inclusus... Noribergae: In Officina Theodorici Gerlachii, 1575. This document has been scanned and is freely accessible via the Digital Collections portal of the Bayerische Staatsbibliothek in Munich, at page: http://stimmbuecher.digitale-sammlungen.de/ view?id=bsb00073117 (06.01.16). 
graphies converge at so many interesting points, that it seems the least to suppose that the two composers knew each other. Silesia could have been the place where they both met, since both of them had spent some time in Breslau (Wrocław) and Liegnitz (Legnica). But Prague is another possible, and even more probable, location for their meeting. Knöfel settled there around 1585, that is, exactly at the same time as Handl, in order to become cantor at the Lutheran (neo-Utraquist) Church and school of Saint-Henry, with its famous choir, and which was probably the place where some of Handl's most faithful supporters and friends in Prague were also working ${ }^{20}$.

In spite of this number of antecedents to the Opus musicum, none of them can really serve as the basis for a detailed comparison with Handl's collection for the reason that they are all collections of polyphonic mass propers, with liturgical chant melodies well identified, and which all clearly bear the marks of their origins, and of their liturgical structure. A mere typographical comparison between these examples and the Opus musicum is enough to realise that an essential element is lacking in the Gallus publication: nowhere within it do we find a liturgical labelling of the pieces, not in their title, in their presentation, or even in the dispositions of the parts, since no cantus firmus is explicitly mentioned as such in the polyphony.

\section{Secondary evidence}

References made to the Opus musicum in secondary literature are plentiful as already mentioned, but only in exceptional cases do they examine the question of liturgy. Of the two important monographs devoted to the Opus musicum, the one authored by the Slovenian composer Lucijan Marija Škerjanc ${ }^{21}$, published in 1963 in Ljubljana, is the only complete and detailed analysis devoted to every one of the 374 motets, representing one of the most ambitious attempt to examine in detail the art of the composer up to this day. Mostly concerned by voice leading in counterpoint and to questions of modality, of harmonic sonorities and clashes of chords due to false relations, or to word- and tonepainting effects, this study completely leaves aside the question of an eventual inclusion of the pieces within a liturgical context. The monograph by Stefan Pontz, some thirty years later ${ }^{22}$, comes with a different and more historical approach to modality, analysed in association with the question of clefs and key signatures in the whole Opus musicum. Gallus' musical language is presented as both illustrating the categories of traditional modality and also the growing interest for a reduction of modal scales to two basic ones, according the whether the aspect of its third is major or minor. No allusion to liturgy is

20 See IN TUMULUM Iacobi Handelii Carnioli... Pragae: In Officina typographica Georgii Nigrini [1591]. Three of the four authors of commemorative verse published on the occasion of Handl's death in 1591 are linked to this place: Jan Khernerus of Pilsen, Martin Galli Černovický and Jan Mathiolus Vodniansis. About this document, see ŠKULJ, Gallusovi, op. cit., p. 118-123.

21 See fn. 7 no. 1$)$.

22 See fn. 7 no. 2). 
to be found in this study either. Among the remaining documents, special attention must be given to the writings of professor Edo Škulj, musicologist and theologian responsible for the establishment of the latest critical edition of the Opus musicum, published between 1985 and 1991 in Ljubljana ${ }^{23}$ and also of the first thematic catalogue available on Handl's complete works ${ }^{24}$. Edo Škulj's two main articles ${ }^{25}$ on the liturgical contents of the Opus musicum include a detailed analysis of the calendar illustrated by the order of the motets, but do not consider the discussion about the motets themselves other than in relation with the biblical origin of their texts, disregarding the liturgical. No mention is made of an eventual liturgical origin of the music itself, nor is it clearly specified that the music could have been conceived independently from plainchant quotations.

A similar conclusion can be made when browsing through the doctoral dissertation of Louard Egbert, submitted to the University of Kentucky in $1975^{26}$ and devoted to the question of performance practice of the Opus musicum. When considering the question of liturgy in introduction, Egbert mentions general sources such as the pre-Tridentine Roman breviary, or a Prague breviary from $1517^{27}$, but only in relation to words, not to chant melodies.

Thus, there remains only a single tool at our disposal in order to consider a study of the eventual presence of liturgical sources in the Opus musicum, namely the first critical edition established by Josip Mantuani for Artaria Editions in Vienna for the Denkmäler der Tonkunst in Österreich (D.T.Ö.) series between 1899 and $1919^{28}$, and whose critical apparatus of the liturgical sources was achieved in collaboration with Mantuani's associate, Emil Bezecny. Conceived as a substantial addendum to each volume, this analysis mentions possible liturgical and/or biblical sources for each motet, as well as the eventual presence of a chant quotation within the polyphony. Although it now appears necessary to take into account the venerable age of this publication, the fact that such a detailed apparatus remained unparalleled in subsequent Gallus studies is in a way symptomatic of the difficulties inherent to the task ${ }^{29}$. It is interesting to consider the global picture that emerges in a reading of this critical report. The detailed examination of the references made by Mantuani-Bezecny can be found below, established on the basis of a sample limited to forty motets (that is, a little more than $10 \%$ of the whole collection), chosen arbitrarily from Motet no. 65 to Motet no. 85 in both cases from Tome I and Tome IV respectively.

\section{See fn. 5 no. 2).}

24 ŠKULJ, Edo. Gallusov katalog [Gallus catalogue]. Ljubljana: Družina, 1992. This catalogue gives for each motet the transcription of the complete Latin text, given with a Slovenian translation. Not mentioning sources however, it has been superseded in 2012 by Marko Motnik's publication.

25 See fn. 8 nos. 1) and 4).

26 See fn. 6.

27 EGBERT, op. cit., p. 64.

28 See fn. 5 no. 1 ).

29 In his correspondence, Mantuani has to argue that he requires a proper liturgical identification of the pieces, not only textual. Cf. HILSCHER, Elisabeth T. Josef Mantuani und Guido Adler: Der Briefwechsel in Archiv der Gesellschaft zur Herausgabe von Denkmälern der Tonkunst in Österreich. In Mantuanijev Zbornik [Mantuani collection]. Edo Škulj (ed.). Lubljana: Družina, 1994, p. 23-74, and especially a letter to Guido Adler dated December 10, 1912 (p. 51). 


\section{Presence of a Cantus Firmus: 2}

Media vita $\mathrm{OM} \mathrm{I}, 65$

Pater noster OM I, 69

\section{Texts from Proprium Missae: 8}

Introitus: 1

Multae tribulationes justorum [Two different introits assembled] OM IV, 85

Gradualia: 1

In Domino speravit OM I, 83 modified

Versus Alleluiatici: 2

Tota pulchra es [prima pars] OM IV, 69a

Tanto tempore OM I, 82

Tractus: 1

Ave Maria OM I, 70

Offertoria: 2

Ave Maria OM I, 70

Ave Maria OM IV, 73

Communiones: 1

Domine Jesu Christe OM I, 76 modified

\section{Texts from Canonical Hours: 39}

Matutinum: 22

Responsoria: 12

Domine Jesu Christe OM I, 76 modified

Lamentabatur Iacob OM I, 78

Locutus est Dominus [prima and secunda pars on two different responses, the second one modified] OM I, 80

Fratres mei OM I, 81

Elegit eam Deus OM IV, 65

Tota pulchra es [prima pars] OM IV, 69a

Domine, quando veneris OM I, 84 modified

Nativitas tua Dei genitrix OM IV, 72

Ecce ego mitto vos OM IV, 77

Ego sum vitis vera $\mathrm{OM} \mathrm{IV}, 78$

Beatus Andreas OM IV, 79

Stola iucunditatis OM IV, 84

Antiphonae: 4

Erravi [secunda pars] OM I, 75b

Revertere Sunamitis OM IV, 66

Tota pulchra es [secunda pars] OM IV, 69b

Nigra sum [beginning] OM IV, 74 
Psalmi: 1

Usquequo Domine [ps. 12] OM I, 67

Versiculi psalmorum: 3

Deus, iniqui [ps. 85, 14-16] OM I, 72

Domine ante te [prima pars: ps. 37, 10-13 - secunda pars: ps. 37, 13-16] OM I, 73

Usquequo Domine [prima pars: ps. 78, 5; 8-9] OM I, 79a

Versiculi post Responsorium: 1

Sancti per fidem OM IV, 75

Versiculi Lectionarum: 1

Dederunt Apostoli sortes OM IV, 81

Laudes: 8

Psalmi: 1

Miserere mei Deus [prima pars: ps. 50, 3 - secunda pars: ps. 50, 4-5 - tertia pars: ps. 50, 12-15] OM I, 82

Antiphonae: 4

Beata es Virgo [two antiphons assembled] OM IV, 68 modified

Tota pulchra es [prima pars] OM IV, 69a

Nigra sum [beginning] OM IV, 74

Tanto tempore OM IV, 82

Antiphonae ad Benedictus: 3

Dum aurora OM IV, 67 modified

Ave Maria OM IV, 73

Quia vidisti me, Thoma OM IV, 80

Vesperae: 8

Antiphonae: 3

Tota pulchra es [prima pars] OM IV, 69a

Nigra sum [beginning] OM IV, 74

Tanto tempore OM IV, 82

Antiphonae ad Magnificat: 4

Extollens quaedam OM IV, 70 
Sancti et justi OM IV, 76

Quia vidisti me, Thoma OM IV, 80

Hodie Simon Petrus OM IV, 83

Versiculi - Responsoria: 1

Exaltata est sancta Dei genitrix [ex hymno] (OM IV, 71)

Completorium: 1

Antiphonae (ante Canticum Simeonis): 1

Salva nos Domine OM I, 71

\section{Common prayers: 1}

Pater noster OM I, 69

\section{Texts known from contemporary sources: 2}

Antiphona: Media vita OM I, 65

Canticum de morte : Audi tellus OM I, 66 (cf. Thesaurus Hymnologicum, p. 350)

\section{Liturgically unidentified: 6}

Converte OM I, 68 (on Esther 13, 17)

Quid gloriaris OM I, 74 (on Ps. 51, 3-11)

Erravi sicut ovis [prima pars] OM I, 75a (on ps. 118, 176)

Nos alium OM I, 77 (on Judith 8, 19b; 14b; 16a)

Usquequo Domine [secunda pars] OM I, 79b (on ps. 84, 6-9)

Patres, qui dormitis OM I, 85

Texts supposed to have been present in liturgical sources of the time: 6

Erravi sicut ovis [prima pars] OM I, 75a

Nos alium OM I, 77

Patres, qui dormitis OM I, 85

Tota pulchra es OM IV, 69

Nigra sum OM IV, 74

Multae tribulationes justorum OM IV, 85

Observing the table resulting from the liturgical distribution established in the D.T.Ö. for this forty-motet sample, caution should be taken in that the editors have limited the mentions of musical cantus firmus to the cases of complete quotations of melodies. Although this precaution is comprehensible when considering the possibility of labelling motets as "cantus firmus" compositions, it leads Mantuani-Bezecny to completely disregard simple allusions to chant melodies. One example of this can be found in the two Ave Maria motets (OM I, 70 and OM IV) of which the first appears to be precisely exhibiting the typical Antiphon incipit at its beginning, meanwhile the second does not 
refer to this chant, nor to the Mass Offertories melodies. Not taking this difference into account, the editors mention an offertory, even a tractus, as at the textual original of both of the pieces, without considering that the musical incipit of OM I, 70 could only make it match an Office antiphon and not a Mass chant. It is therefore unexpected that, examining liturgical sources for OM I, 70, they should not have mentioned the Vesper (or Lauds) antiphon, while they have done so for OM IV, 73, a motet which does not refer to that antiphon melody!

In front of such a clear case, it seems obvious that the mapping of liturgical roots, textual and/or musical, will only be achieved through a careful and complete filtering through this first critical apparatus. In spite of its limitations, the table of sources indeed helps us to consider Handl's motets from at least two points of view:

1) As far as music is concerned, and regardless of the necessary precautions mentioned above, cantus firmus pieces seem only to represent a minority of cases in this sample. The fact that chant melodies do not appear ${ }^{30}$, or that they should be reduced to a mere incipit even in such famous cases as is the Ave Maria antiphon above, seems to point towards a collection mostly conceived outside of obvious liturgical connections. The absence of chant melodies for the great propers of the Mass or responses from the Offices also explains how the editors came to associate some of the texts to several different liturgical moments. One could argue, of course, that Gallus could have followed a melodic model, foreign to those with which the editors were familiar, and that the investigation for melodic quotations should continue. But even this hypothesis seems difficult to sustain in view of the very large majority of pieces that would have to be considered in that way.

2) On the other hand, the texts of the motets issue predominantly from the antiphonarium, although many of them seem to result from combination of several fragments, a fact that is also in favour of a non-cantus firmus conception. One can only admire, some 110 years after its publication, the sagacity of the editors, who suspected that other sources could have been used in the compositions. This is true of the seven motets whose texts display variants from the liturgical sources known to the editors (and labelled in the above table as "modified"), but this is especially true of the six liturgically unidentified pieces, out of which three are mentioned as "probably" originating from sources known at the time of Gallus, alongside three others resulting from a combination of different liturgical fragments. Interestingly enough, the consultation of up-todate and commonly available research tools such as chant databases online prove that two of these six pieces still resist, as texts, liturgical identification ${ }^{31}$. More interestingly even, the only piece whose origin cannot be traced either in the Scriptures nor in liturgy,

30 A good example is the motet Tota pulchra es (OM IV, 69), which not only does not betray any chant quotations, but echoes instead in its incipit the very beginning of the famous spiritual song Suzanne un jour by Lassus (first published in 1560).

31 These are Quid gloriaris (OM I 74) and Usquequo Domine (OM I, 79), which, also identified in their biblical origin, do not bring any identification in the Cantus Database <cantusdatabase.org> (16.01.16). This research tool helps us on the other hand identify three other texts in the list: the prima pars of Erravi sicut ovis (OM I, 75 ) is mentioned as a Versiculus for Lent Sundays; Converte Domine (OM I, 68) and Nos alium (OM I 77) are associated to a Versiculus and a Response respectively, for the feasts 'De Esther' and 'De Judith'. 
Patres qui dormitis (OM I, 85), appears in a Latin translation of a Hebrew prayer for the deceased, published by Gilbert Génébrard in 1569 in an edition of Jewish articles of faith after Maimonides ${ }^{32}$.

We should therefore consider that the study of the Opus musicum in its liturgical aspect is marked by a great deal of ambiguity: all scholars who have dealt with the collection mention it as a companion to other great liturgical cycles (Isaac, Päminger) that do not really correspond to it, however no clear information is to be found as to whether this collection would have been or would not have been conceived after a plainchant model, or according to a definitive liturgical use. A brief survey of a sample of forty motets does not bring any satisfactory supplement to the melodic identification from more than a century ago, leaving unsolved the question of the not yet identified sources. At this point, we can only suggest the hypotheses that:

- either the Opus musicum is not conceived as a collection for liturgical use, but includes only motets simply grouped in the calendrical ordering of the Church;

- or there exist one or more specific liturgical sources to which the compositions of the collection refer, sources which, being not yet identified, do not reveal the proper liturgical context of the collection.

As mentioned above, the hypothesis of one unknown liturgical source is rather naive. Could there be such a thing as one and only liturgical source for such a collection, when we remember that the composer's life prior to his settlement in Prague in 1585 was a wandering one indeed? The logical negation makes it obvious that if a liturgical background is to be found within the Opus musicum, then this background is multiple and necessarily varied. We can indeed only suppose that, given the different contexts in which Handl has worked, the liturgical practice that he encountered must have been very different from one place to another. These contexts include monastical centres such as the Benedictine abbey of Melk and the Pramonstratensian monastery of Zábrdovice; the milieu of the cathedral or episcopal chapel at Olomouc when he was in the service of the Olomouc bishop, Stanislav Pavlovský; contexts linked to the activities of the Olomouc Jesuits; and finally the environment of the great churches of Breslau (Wrocław) such as the Lutheran Saint-Elisabeth or the Catholic cathedral Saint John the Baptist, if not the Ducal chapels of Liegnitz (Legnica) and Brieg (Brzeg). However if we want this picture to be complete, we have to add, of course, the typical Prague context of Gallus' last years, and the liturgical habits and practice of the venerable romanesque church of Saint John where the composer lived his last years, and prepared his work to be printed at Jiří Nigrin's workshop. To suppose that Gallus' creations would conform to liturgical use, corresponding to the contexts mentioned above would therefore imply that the Opus musicum reflects a multiple liturgical practice. In other words, if we suppose that this music can be of liturgical use, then it is not one source which we should suspect

32 GÉNÉBRARD, Gilbert, ed. Symbolum fidei Iudaeorum è R. Mose Agyptio. Parisiis: apud Martiunum Iuvenem, 1569 , p. 22. This text, which does not seem to have generated any other musical treatment during the Renaissance, is one of the rare gems of the Opus musicum. It will be the subject, together with other unica found in this collection, of a forthcoming article. 
as being the basis of the Opus musicum, but several, which takes us even further from a simple answer to the question.

\section{Other directions}

The expression used on the title-page of the Opus musicum is interesting since it can send us in another direction.

Tomus primus [- quartus] musici operis, harmoniarum quatuor, quinque, sex, octo et plurium vocum, quae ex sancto catholicae ecclesiae usu ita sunt dispositae, ut omni tempore inservire queant.

First (- fourth) tome of the musical work, containing harmonies of four, five, six, eight, and more parts, which have been disposed according to the use of the Catholic church in such a way, that they can serve in all seasons.

In other words, the pieces have been disposed and distributed in the collection in order to be used in all seasons. Not each piece for every season of course, but, according to the liturgical season, one or several pieces can be used. This idea of distribution takes its full meaning if we want to consider that with the Opus musicum, Handl disposes in calendrical sequence motets composed since the years 1575 until their date of print. The sources themselves give a testimony of this state of affairs, and the Silesian manuscripts, in particular, attest to the existence of pieces before their printed publication ${ }^{33}$. In his 'Instructio ad musicos' [Instructions to musicians] ${ }^{34}$, addressed to choir directors, the composer insists upon the liturgical order. He declares having:

1) used only texts which correspond to one given period, and not texts which are recurrent throughout the year ${ }^{35}$;

2) followed the liturgical order, so that he could be as close as possible to the meaning of the words in his music ${ }^{36}$;

33 A detailed survey of the vast amount of Handl sources originating from Silesia has been published by JEŻ, Tomasz. Twórczość Jacoba Handla w źródłach proweniencji Sląskiej [The work of Jacobus Handl in sources of Silesian proveniance]. Muzyka, 2004, vol. 49, no. 4, p. 27-62. Some motets published in Tome IV of the Opus musicum (1591), including the widespread Elisabethae vero impletum est tempus (OM IV, 20) and Elisabeth Zachariae (OM IV, 53) were already in manuscript circulation as early as the 1580's. Gallus' mass on Elisabeth Zachariae was already published in 1580 (Selectiores quaedam missae, Liber II, Prague, Nigrin, 1580).

34 'Instructio ad musicos', Opus musicum III, Prague 1587, f. [3-4].

35 Nam exempli causa pro iis, quae ex Bibliis, et Prophetis toto anno proponuntur, ego quae ex omnibus selectissima quolibet die fuerunt, cantui segregavi. [And for example, instead of the chants from the Bible or the Prophets which are presented all year long, I selected those which, among all of them, would be best chosen for a specific day]. 'Instructio... ', f. [3v].

36 ... sicut ab Ecclesiae ordine, quem semper optimum judicavi, nusquam recessi, neque in posterum recessurus sum, ita ex ipsius verbis ea delegerim, quae ad cantum et ad dies sacros accommodissima putavissem. [... never having deviated nor willing to deviate in the future from the Church calendar, which I have always considered to be the most 
3) and he also recommends to musicians the greatest attention in the choice of pieces in order to avoid confusion ${ }^{37}$.

Nothing clearly indicates in this text that plainchant melodies were used or ignored, but it nevertheless seems clear that the composer explains his decision to follow the liturgical calendar as an expression of his artistic freedom. Should we infer from this assertion that we are dealing here with ecclesiastical concerts more than with polyphonic settings of liturgical chants? Such a deduction seems too hasty indeed, although it does not sound at odds with the composer's words either.

In order to complete this general picture of musical and liturgical structure in the Opus musicum, it is of note that the ordering of the collection also suggests other directions of research. Each tome is organised according to liturgical subsections, themselves ordered according to a decreasing number of parts. It is a general case that the last piece(s) of a section almost always display(s) an extra peculiarity in that it is often written for voices ad aequales, or feature(s) something more in its compositional device such as a canon or a notational difficulty.

Tome I, which comprises 103 motets, adds to this double ordering (liturgical sub-sections + decreasing number of parts) a modal classification which seems to have escaped the attention of previous scholars. This order is always the same in the 'Advent' section: in first place, modes with minor third, and in the second, modes with major thirds ${ }^{38}$. It is inverted from the 'Christmas' section onwards. The pieces ad aequales, which conclude the sections, escape this alternation between modal types, an exception that in some way confirms their structural location within the order of motets. This modal ordering appears to be so strong, that only three motets out of a total of 103 do not conform to it: Omnes de Saba (OM I, 55) Locutus est Dominus (OM I, 82) and Fratres mei (OM I, 83), which are all three in Ionian mode inside the minor third modes section.

In Tome II, pieces for Passion time are classified in sections according to the number of parts, but these are limited to a few pieces each and do not make it possible to display a modal ordering. Passions and Lamentation cycles are long pieces that do not fit well into this frame, and the few remaining motets do not appear numerous enough to allow the repetition of the same structure. Starting from the subsections devoted to 'Easter' and 'Pentecost', the succession of pieces is again as numerous as in Tome I. But we do not find in them any trace of modal ordering. The pieces follow one another seemingly without having been grouped according to their mode. This fact is emphasised by another characteristic, which is the extreme stylistic unity of all these motets ${ }^{39}$. The

appropriate, I have chosen from its texts what appeared to me to be the most adapted to singing and to the feasts]. 'Instructio...', f. [3].

37 Restat, ut vos, qui in aedibus sacris Symphoniae praeestis, obtester, singula ut suis temporibus accommodetis, neve confusioni, quae in domo Dei occurreret, locum ulla ratione faciatis ; quod illic forte videtur deesse, alibi resarcietur. [It remains to me to pray you, the directors of musical forces present in the holy sanctuaries, accommodate every piece to the time it befits, and avoid any occasion of whatsoever confusion in the house of God ; if it occurred that something should miss at one point, something else will replace it from another.], 'Instructio... ', f. [3v-5]. 38 Although not noticed by Pontz, this clear division presents a strong argument in support of his observations about the « modern » aspect of modality in Handl's motets. See PONTZ, op. cit.

39 OM II 29 up to OM II, 70. 
works of the 'Easter' section seem to share a late style, adopting a Counter-Reformation manner with clear declamation alternating with alert and rhythmicized Alleluias ${ }^{40}$. It is as if these pieces had been gathered together in haste, without possibility of a modal ordering. Although these motets of a later and more unified style would seem to lend themselves best to an enquiry concerning the detection of chant melodies, it has not yet been possible to identify in them clear chant quotations. Motets of the 'Pentecost'41 section display, on the other hand, exactly the opposite tendency, with a florid and complex counterpoint being at times associated with elaborate notational devices. The style of these motets is at times almost instrumental, evoking the nature of a Canzona ${ }^{42}$, and we find in them the longest and most abstract Alleluias in all of Handl's works ${ }^{43}$. Modal ordering does not seem apparent either in this section, probably for the same reasons.

There is no modal ordering discernable in Tome III either, the shortest of the four with its 57 motets, probably again because new criteria of ordering appear in this tome as well, alternating different liturgical subsections inside larger units defined by the number of parts. The 31 motets that conclude this third tome are devoted to the long period of time situated between Corpus Christi and Advent. They build apparently the least organised section of the whole collection, given the fact that even the part settings do not follow the decreasing order observed everywhere else in the Opus musicum. This relative disorganised succession is an indication that these motets were potentially gathered in haste, while they seem to mirror the necessities of the yearly calendar, there are only a small number of motets left to illustrate the summer part of "tempus per annum", regardless of their mode or setting. ${ }^{44}$.

Tome IV probably helps us to understand the reason of this apparent disparity. In this tome, the subsections correspond to the divisions of the sanctoral with commons of martyrs, of virgins, of apostles, Marian feasts, etc. To these general divisions are added a number of specific divisions devoted to a special feast for a single day of the calendar, such as Saints Peter and Paul, Saint Thomas, or Saint Mathias for example. The classification is therefore threefold: voice setting, divisions of the sanctoral, and special feasts, to which must be added, as in Tome I, the motets ad aequales or special motets for conclusions of sections. Interestingly enough, several motets following each other on the same theme, without another key of ordering, show that, once more, a modal classification prevails. A great part of the motets contained in this tome is formed by works belonging to two different stylistic trends: either light works with rapid and homophonic declamation clearly similar to the one used in the Harmoniae morales or the Moralia, the last published collections by the composer ${ }^{45}$, or, on the other hand, complex works that

40 e.g. OM II, $43,44,45 \ldots$

41 OM II 56 up to OM II 70.

42 e.g. OM II, 62

43 e.g. OM II, 63

44 This small number probably also explains why motets for the Dedication should have been added here instead of being more logically placed in Tome IV.

45 e.g. OM IV, 42, 50, 51, 77, 79... 
have dense and florid counterpoint, sometimes evocative of an instrumental Canzona ${ }^{46}$. Two compositions emblematic of this last type, the motets for Saint John the Baptist Elisabethae vero impletum est tempus (OM IV, 20) and Elisabeth Zachariae (OM IV, 53) can, with certitude, be assigned to the Silesian years of the composer, that is, the latter years of the $1570 \mathrm{~s}^{47}$. It is therefore not impossible that, with the group of motets sharing the same stylistic features, we could isolate a more ancient, and possibly Silesian group of compositions within the Opus musicum, preeminent both in this section and the 'Pentecost' subsection of Tome II.

\section{Conclusions}

The liturgical study of the Opus musicum needs to be taken into consideration. It is a serious missing point from all literature written to this day. The detailed critical apparatus provided in the Mantuani-Bezecny edition can serve as a basis, requiring complements for simple chant allusions and a new survey of available chant sources. This study can only be successful if we take into account obstacles that are to be avoided regarding the objective and also the method of this research. It seems indeed necessary to renounce considering the Opus musicum as a homogeneous collection, and cease to make it a companion of Isaac's Choralis Constantinus, Byrd's Gradualia, or even the Päminger's or Knöfel's collections, which have all been conceived around explicit use of chant melodies. These associations to the Opus musicum do not withstand the examination of these sources, or the fact that it is impossible to imagine a single liturgical provenance for Handl's motets. In terms of method, it should also be necessary to take into account the complex nature of the object edited under the name Opus musicum. Under the appearance of a uniform collection, a musical totality has been gathered which is situated at the cross-roads of at least three distinct fields:

- that of the multiple liturgical contexts that witnessed the birth of the musical compositions: monastic, parish, episcopal on the Catholic side, but also Lutheran and Hussite;

- that of the stylistic evolution of the composer, writing over different stages of his life for varied musical forces (equal voices, great choirs, or modest vocal ensembles), and adapting itself to contexts that require sometimes more elaborate and composed music, and sometimes lighter and more declamatory forms.

- and finally, that of the constitution of a printed object, which adds its own constraints to the global realisation of a work: page settings, disposition of sections, groupings of pieces at certain places within the books, eventual modal ordering of some groups of pieces ${ }^{48}$, etc. We should here recall that the composer was deeply involved in

46 e.g. OM IV, 64, 107, 133...

47 Their earliest sources, in manuscript form, being from Breslau (Wrocław) provenance.

48 For a recent account on the influence of typographical constraints on printed music, see GANCARCZYK, Paweł. La Musique et la révolution de l'imprimerie, les mutations de la culture musicale au XVIe siècle, french 
the printing of his own creation, especially with the help of his brother, whose role we now suspect to be all the more significant, both in Prague and in Nuremberg ${ }^{49}$. From this point of view, it is not the liturgical collections of Isaac, Päminger or Knöfel which can be used as comparison, but more the anthologies of the Italian masters compiled in Nuremberg by Friedrich Lindner and printed at the Gerlach workshop under the title Cantiones Sacrae in three volumes, an anthology that Handl had in his possession ${ }^{50}$.

Unless liturgical sources are found that would make it possible to link all or part of the Opus musicum motets to a precise context, we are reduced, for now, to follow a hypothesis. Far from being an homogeneous collection, the Opus musicum assembles motets conceived at different times, which can be adapted to the liturgical calendar in the manner of musical ornaments, or ecclesiastical concerts, possibly added to the ceremonies of the day, or else possibly, and as convincingly, sung outside of any given liturgical or ceremonial context. Contrary to the collections of polyphonic propers, with which this Opus musicum has been all too often compared, Handl's motets do not seem to educate us about a singular liturgical context, but much more about the importance of music in the different liturgical contexts that Handl encountered throughout his life.

It has recently been remarked ${ }^{51}$ the extent to which the study of Handl's masses, all published in $1580^{52}$, was deterring us from granting too much credit to the fiction told in the foreword, according to which the number of parts was proportional to their date of composition. It is to a similar statement that the not-yet-realised study of the Opus musicum seems to invite us: having started our enquiry in order to find liturgical traces, on the way we may uncover stylistic layers, which will tell us much more about the different episodes of Gallus' musical creation. Studies such as this are exactly the kind that are still lacking for a great amount of Renaissance music, not only for Gallus.

translation by Wojciech Bońkowski. Lyon: Symétrie, 2015 (orig. Polish publ. Muzyka wobec rewolucji druku, Toruń, 2011), and especially Chapter 4, "L'Imprimerie et le marché musical”, p. 73-119.

49 The latest accounts on Georg Handl activities as a printer can be found in DESMET, Marc. "Typographicum robur fractum", Jacob Handl's relationship with the printing press. De musica disserenda, 2007, vol. 3, no. 2, p. 13-25, and, by the same, "Gallus apud Belgas" or the Douai Moralia (1603) reconsidered. De musica disserenda, 2015, vol. 11, nos. 1-2, p. 67-86.

50 LINDNER, Friedrich ed. Sacrae Cantiones [Continuatio / Corollarium Cantionum Sacrarum]. Noribergae: In officina typographica Catharinae Gerlachiae, 1585 [- 1590]. These sources have been scanned and are freely accessible via the digital collections portal of the Bayerische Staatsbibliothek in Munich. See, for Tome I: http://stimmbuecher.digitale-sammlungen.de/view?id=bsb00071888 (18.01.16).

51 DESMET, Marc. Establishing a chronology of Jacob Handl's printed masses. Evidence and problems. In The Musical Heritage of the Jagiellonian Era. Paweł Gancarczyk - Agnieszka Leszczyńka (eds.). Warszawa: Instytut Sztuki PAN, 2012, p. 155-168.

52 HANDL GALLUS, Jacobus. Selectiores quaedam missae, Liber I. Pragae: Ex officina Nigriniana, 1580. This source has been scanned and is freely accessible via the Digital Collections of the Bayerische Staatsbibliothek in Munich. See, for Tome I: http://stimmbuecher.digitale-sammlungen.de/view?id=bsb00094191_(23.01.16). 


\section{Bibliography}

\section{Sources}

CONTRAPUNCTUS, seu figurata musica super plano cantu missarum totius anni, Lugduni, in edibus Stephani Guaynard, 1528. http://gallica.bnf.fr/ark:/12148/btv1b8538821j.r=Contrapunctus (06.01.16).

GÉNÉBRARD, Gilbert, ed. Symbolum fidei Iudaeorum è R. Mose Egyptio. Parisiis: apud Martiunum Iuvenem, 1569.

HANDL GALLUS, Jacobus. Selectiores quaedam missae, Liber I. Pragae: Ex officina Nigriniana, 1580. http://stimmbuecher.digitale-sammlungen.de/view?id=bsb00094191 (23.01.16).

HANDL GALLUS, Jacobus. Tomus primus [-quartus] Musici operis... Pragae: Typis Georgii Nigrini, $1586[-1591]$.

http://daten.digitale-sammlungen.de/ db/0009/bsb00092000/images/?viewmode=1 (14.11.15).

ISAAC, Heinrich. Primus [-Tertius] tomus Coralis [ !] Constantini. Nornbergae: Hieronymus Formschneider, 1550 [-1555].

http://stimmbuecher.digitale-sammlungen.de/view?id=bsb00094084 (18.01.16).

IN TUMULUM Iacobi Handelii Carnioli... Pragae: In Officina typographica Georgii Nigrini [1591].

KNÖFEL, Johannes. Cantus choralis, musicis numeris quinque vocum inclusus... Noribergae: In Officina Theodorici Gerlachii, 1575.

http://stimmbuecher.digitale-sammlungen.de/view?id=bsb00073117 (06.01.16).

LINDNER, Friedrich ed. Sacrae Cantiones [Continuatio / Corollarium Cantionum Sacrarum]. Noribergae: In officina typographica Catharinae Gerlachiae, 1585 [-1590].

http://stimmbuecher.digitale-sammlungen.de/view?id=bsb00071888 (18.01.16).

PÄMINGER, Leonhard. Primus [-Quartus] tomus ecclesiasticarum cantionum... Noribergae: In Officina Theodorici Gerlazeni, 1573-1580.

http://stimmbuecher.digitale-sammlungen.de/view?id=bsb00072013 (06.01.2016).

\section{Literature}

ACCIAI, Giovanni. Espressione e artificio in alcuni motetti dell’ „Opus Musicum“ di Jacobus Gallus Carniolus. In Gallus Carniolus in evropska renesansa II [Gallus Carniolus and the European Renaissance]. Edo Škulj - Danilo Pokorn (eds.). Ljubljana: Slovenska Akademija Znanosti in Umetnosti, 1992, p. 49-78.

BLUME, Friedrich. Protestant Church Music. London: V. Gollancz, 1975 (revised edition from the German original, 2/1965).

DESMET, Marc. Establishing a chronology of Jacob Handl's printed masses. Evidence and problems. In The Musical Heritage of the Jagiellonian Era. Paweł Gancarczyk - Agnieszka Leszczyńka (eds.). Warszawa: Instytut Sztuki PAN, 2012, p. 155-168.

DESMET, Marc. Façade et revers d'une architecture musicale solennelle : la structure de l'Epicedion Harmonicum de Jacobus Handl (Gallus) et ses énigmes non résolues. De musica disserenda, 2014, vol. 10, no. 2, p. 101-123. 
DESMET, Marc. "Gallus apud Belgas" or the Douai Moralia (1603) reconsidered. De musica disserenda, 2015, vol. 11, nos. 1-2, p. 67-86.

DESMET, Marc. "Typographicum robur fractum”, Jacob Handl's relationship with the printing press. De musica disserenda, 2007, vol. 3, no. 2, p. 13-25.

EGBERT, Louard Edward Jr. The Opus Musicum of Jacobus Gallus: Performance problems of selected motets. PhD. University of Kentucky, Princeton (KY) 1975.

FISCHER, Kurt von. Die Passions-Motetten des Jacobus Gallus und ihre Beziehungen zur Passion des Antoine de Longavals. In Gallus Carniolus in evropska renesansa I [Gallus Carniolus and the European Renaissance, I]. Edo Škulj - Danilo Pokorn (eds.). Ljubljana: Slovenska Akademija Znanosti in Umetnosti, 1991, p. 63-70.

GANCARCZYK, Paweł. La Musique et la révolution de l'imprimerie, les mutations de la culture musicale au XVIe siècle, french translation by Wojciech Bońkowski. Lyon: Symétrie, 2015 (orig. polish publ. Muzyka wobec rewolucji druku. Toruń, 2011).

HEYINK, Rainer. Die Passionsmotette von Antoine de Longueval, Herkunft, Zuschreibung und Überlieferung. Archiv für Musikwissenschaft, 1990, vol. 47, no. 3, p. 217-244.

HILSCHER, Elisabeth T. Josef Mantuani und Guido Adler: Der Briefwechsel in Archiv der Gesellschaft zur Herausgabe von Denkmälern der Tonkunst in Österreich. In Mantuanijev Zbornik [Mantuani collection]. Edo Škulj (ed.). Lubljana: Družina, 1994, p. 23-74.

JEŻ, Tomasz. The Motets of Jacob Handl in inter-confessional Silesian liturgical practice. De musica disserenda, 2007, vol. 3, no. 2, p. 35-46.

JEŻ, Tomasz. Twórczość Jacoba Handla w źródłach proweniencji Śląskiej [The work of Jacobus Handl in sources of Silesian proveniance]. Muzyka, 2004, vol. 49, no. 4, p. 27-62.

MANTUANI, Josip - BEZECNY, Emil, eds. Jacobus Handl (Gallus) Opus Musicum, Wien: Artaria, 1899-1919 (Denkmäler der Tonkunst in Österreich, nos. 12, 24, 30, 40, 48, 51/52), 6 vols.

MOTNIK, Marko. Jacob Handl-Gallus, Werk-Überlieferung-Rezeption, mit thematischem Katalog. Tutzing: Hans Schneider Verlag, 2012. (Wiener Forum für ältere Musikgeschichte, ed. Birgit Lodes, Bd. 5).

PONTZ, Stefan. Die Motetten von Iacobus Gallus, Untersuchungen zu den Tonarten der klassischen Vokalpolyphonie. München: Wilhelm Fink, 1996 (Studien zur Musik, hsg Eudolf Bockholdt, n 15).

ŠKERJANC, Lucijan Marija. Kompozicijska tehnika Jakoba Petelina Gallusa [The Compositional technique of Jakob Petelin Gallus]. Ljubljana: Slovenska Akademija Znanosti in Umetnosti, 1963.

ŠKULJ, Edo. Bogoslužno leto v Opus musicum [The liturgical year in the Opus musicum]. Cerkveni Glasbenik [The Church musician], 1991, vol. 84, nos. 4-12, p. 125-145.

ŠKULJ, Edo. Gallusov katalog [Gallus catalogue]. Ljubljana: Družina, 1992.

ŠKULJ, Edo., ed. Gallusovi predgovori [Gallus' forewords]. Ljubljana: Družina, 1991.

ŠKULJ, Edo, ed. Iacobus Gallus, Opus Musicum, Ljubljana: Slovenska Akademija Znanosti in Umetnosti, 1985-1990 (Monumenta Artis Musicae Sloveniae, nos. V-XVII), 13 vols.

ŠKULJ, Edo. Vprašanje mere v Gallusovih motetih [The question of measure in Gallus' motets]. Cerkveni glasbenik, 1993, vol. 86, nos. 1/3, p. 62-65.

WACZKAT, Andreas. Parodie-Motetten in Opus musicum des Jacobus Gallus: Wege zu ihrer Identifizierung und Analyse. Tijdschrift voor muziektheorie, 2003, vol. 8, no. 2, p. 123-133.

WINTER, Zikmund. Malé historie ze života staročeského [Little histories from Old Bohemian life]. Velké Meziříćí: J. F. Šašek, 1888.

WILSON, Fredric Woodbridge. Index to the Opus Musicum of Jacob Handl Gallus. In Gallus Carniolus in evropska renesansa II I [Gallus Carniolus and the European Renaissance, II]. Edo Škulj Danilo Pokorn (eds.). Ljubljana: Slovenska Akademija Znanosti in Umetnosti, 1992, p. 207-288. 